\section{Development a cement mortar based on dune sand used as an anti- carbonation coating of concrete}

Youssef KORICHI

PhD Student, Civil engineering department. Researcher, Faculty of Civil Engineering and Architecture, Amar Telidji University of Laghouat, Algeria. His research interests include: concrete durability, concrete carbonation, anti-carbonation coatings.

YousSEF KORICHI - Ammar Thélidji University of Laghouat, Algeria; Civil Engineering Research Laboratory • koryou72@gmail.com

AHMEd MERAH - Ammar Thélidji University of Laghouat,Algeria ; Civil Engineering Research Laboratory - a.merrah@yahoo.fr a.merrah@lagh-univ.dz

Med Mould KHENFER - Ammar Thélidji University of Laghouat,Algeria;

Civil Engineering Research Laboratory • m.khenfer@lagh-univ.dz

Benharzallah KROBBA - Ammar Thélidji University of Laghouat, Algeria; Structure Rehabilitation and Materials Laboratory (SREML) - h.kroba@lagh-univ.dz

Érkezett: 2021. 05. 21. " Received: 21. 05. 2021. " https://doi.org/10.14382/epitoanyag-jsbcm.2022.5

\section{Abstract}

Reinforced concrete structures are exposed throughout their life to the carbonation process due to the inevitable presence of $\mathrm{CO}_{2}$ in the air, which causes corrosion of the reinforcements. In order to limit these harmful effects on reinforced concrete structures, anti-carbonation coatings are used. The purpose of these coatings is to limit the permeability of the embedding concrete to carbon dioxide. Each of these coatings has durability performance in terms of protection against this phenomenon. The main objective of this work is to study the effectiveness of a corrected mortar coating based on dune sand as an anti-carbonation coating of concrete using local materials, not presenting any danger, available in abundance in our countries. The obtained results clearly show that the formulated mortar has a very satisfactory compressive strength, a very low water porosity and the carbonation resistance is increases with the rate $60 \%$ compared to ordinary cement mortar based on alluvial sand.

Keywords: cement mortar, dune sand, coating, anti-carbonation, concrete

Kulcsszavak: cementhabarcs, dūnehomok, bevonat, karbonátosodás gátlás, beton
Ahmed MERAH

Lecturer (MCA), Civil engineering department Research Professor; Faculty of Civil Engineering and Architecture, Amar Telidji University of Laghouat, Algeria. His research interests include: concrete durability, concrete carbonation, anticarbonation coatings.

Mohamed Mouldi KHENFER Professor, Civil ensineering department; Research Professor; Faculty of Civil Engineering and Architecture, Amar Telidji, University of Laghouat, Algeria. His research interests include:

Benharzallah KROBBA Research professor, University of Laghouat, Algeria. His research interests include: formulation of cement reparation mortars, concrete durability, the use of local materials as the dune sand in concrete. The use of local materials, light weight concrete Lecturer (MCA), Department of Civil Engineering,

\section{Introduction}

Carbonation is widely recognized as a major cause of reinforcement corrosion in concrete [1]. The corrosion of reinforcements is shown to be the main cause of deterioration of reinforced concrete structures in the world [2]. With the aim of extending the life of reinforced concrete structures by protecting them against the carbonation phenomenon, several studies have been carried out in this direction using anticarbonation coatings. Organic coatings, inorganic coatings and mortar coatings are the three main classes of anti-carbonation coatings. These coatings are used to form a barrier against chemical attack to protect concrete. They can consist of a single layer, two layers or more. Organic coatings depend mainly on their chemical inertness and their waterproofing. They are easy to apply on surfaces using brushes, sprays or rollers [3].

According to the experimental of José et al and Merah et al. [4,5] epoxy resin-based coatings give better protection against corrosion compared to acrylic coating and resinous cement-based coatings.

Furthermore, polyurethane and acrylic coatings provide better protection against diffusion and chloride permeability and water absorption compared to epoxy and chlorinated rubber coatings [6]. Other research has shown that acrylic coatings can provide a satisfactory level of protection against carbonation, and elastomeric coatings can protect steel bars from corrosion caused by chloride ions [7]. Benshausen et al. [8] concluded that acrylic coatings protect concrete against carbonation compared to cementitious coatings and increase the life of reinforced concrete structures. In this context, several researchers are interested in studying their effectiveness against the phenomenon of carbonation.
For anti-carbonation coatings in mortars, Huseyin et al. [9] and Miguel et al. [10] used mortar coatings composed of a mixture of (portland cement + very fine silica + active organic chemicals) which reduced permeability and minimized carbonation. According to Huang et al. [11]concrete coated with mortar (cement + sand and tile) whose thickness exceeds $50 \mathrm{~mm}$ have high resistance to carbonation. Researches also tested, a cement and sand mortar in two proportions, cement/sand equal to 0.33 and 0.5 , the results obtained show that the mortar with the cement / sand rate equal to 0.5 can reduce the carbonation depth and that the latter is inversely proportional to the thickness of the surface coating [12]. This is, perhaps, explained by the large reserve of portlandite in the mortar made with this rate (cement/sand $=0.5)$ [3]

In addition, cement mortar with a thickness greater than $8 \mathrm{~mm}$ can protect reinforced concrete structures against carbonation for a period of 25 years $[13,14]$

This work is part of the valuation of local materials, which the effect of dune sand corrected based mortars on the durability of reinforced concrete structures against the carbonation phenomenon was studies.

\section{Materials}

\subsection{Sands}

The used alluvial sand comes from the quarry of Oued M'zi near the Laghouat region in Algeria, it is characterized by a regulatory particle size. 
The used dune sand comes from the Laghouat region in Algeria, it is characterized by a regulatory particle size. The physical properties of used sands were presented in Table 1.

\begin{tabular}{lcc} 
& Alluvial sand & Dune sand \\
Max Diameter $(\mathbf{m m})$ & 5 & 0.63 \\
\hline Apparent density $\left(\mathbf{K g} / \mathbf{~ m}^{3}\right)$ & 16.3 & 15.1 \\
\hline Absolute density $\left(\mathbf{K g} / \mathbf{~ m}^{3}\right)$ & 24 & 26 \\
\hline Sand equivalent $(\%)$ & 60 & 97 \\
\hline Fineness modulus & 2.70 & 0.84
\end{tabular}

Table Physical properties of the sands used

1. táblázat Azalkalmazott homok fizikai tulajdonságai

\subsection{Cement}

The used cement is a Portland cement (Algerian Cement) of the CEM I 42.5 CRS. The physical and chemical characteristics are given in Table 2.

\begin{tabular}{|c|c|c|c|c|c|c|c|c|c|}
\hline $\begin{array}{l}\text { Rate } \\
\text { en }\end{array}$ & $\begin{array}{l}\text { C4AF } \\
\text { clinker }\end{array}$ & $\begin{array}{l}\text { C3A } \\
\text { clinker }\end{array}$ & $\begin{array}{l}\text { C2S } \\
\text { clinker }\end{array}$ & $\begin{array}{l}\text { C3S } \\
\text { clinker }\end{array}$ & PA.F & CI & $\mathrm{SO}_{3}$ & $\begin{array}{l}\text { Compressive } \\
\text { strength in } \\
\mathrm{MPa}\end{array}$ & $\begin{array}{c}\text { Specific } \\
\text { surface } \\
\mathrm{cm}^{2} / \mathrm{g}\end{array}$ \\
\hline & 17 & 1.5 & 13 & 62 & 2.04 & 0.028 & 2.30 & 49.5 & 3420 \\
\hline
\end{tabular}

Table 2 Physical and chemical characteristics of the used cement CEMI 42.5 CRS 2. táblázat CEM I 42.5 CRS cement fizikai és kémiai tulajdonságai

\subsection{Super plasticizer}

The superplasticizer used is a MEDAPLAST SP 40 produced by the company Granitex (in Algeria). It is a better water reducer for ready-mixed concrete according to Standard EN 934-2 [15]. It is characterized by a density of $1.20 \pm 0.01$, with $\mathrm{pH}=8$, and a chloride ion content $\leq 1 \mathrm{~g} / \mathrm{l}$.

\section{Preparation of mortars}

To analyse the effect of adding dune sand to the cement mortar in order to choose the most effective mortar against the carbonation a prismatic sample $(4 \times 4 \times 16 \mathrm{~cm})$ for the six mixtures are made (Fig. 1) (Table 3) of different amounts of alluvial and dune sands with CEM I 42.5 cement and superplasticizer (Table 4)

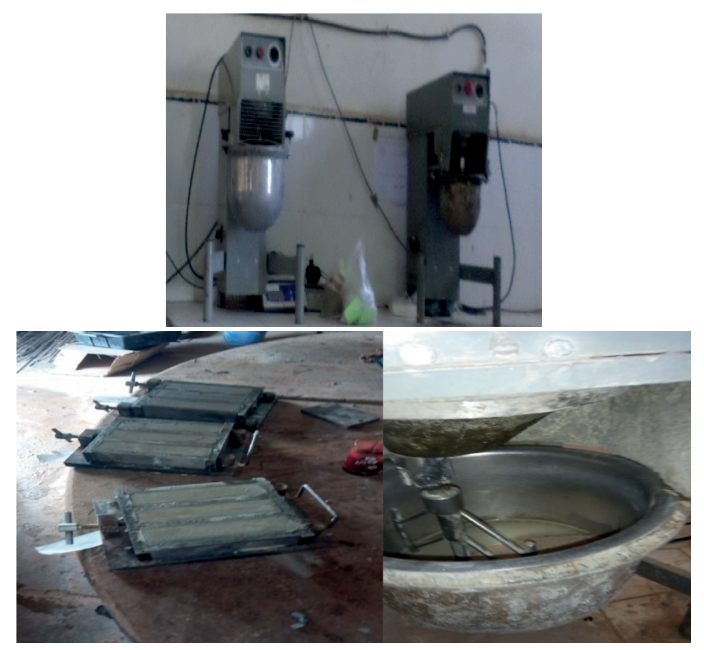

Fig. 1 Preparation of different mortars

1. ábra A habarcs minták elökészitése

\begin{tabular}{ccc}
$\mathbf{N}^{\circ}$ & Compositions of mixtures & $\begin{array}{c}\text { Designations of } \\
\text { mixtures }\end{array}$ \\
\hline $\mathbf{0 1}$ & Alluvial Sand + cement CEMI + water & MSA \\
\hline $\mathbf{0 2}$ & $\begin{array}{l}80 \% \text { of alluvial sand + 20 \% of dune sand + } \\
\text { cement CEMI + water + superplasticizer (Sp). }\end{array}$ & 8MSAD \\
\hline
\end{tabular}

$0360 \%$ of alluvial sand $+40 \%$ of dune sand + cement CEMI + water+ superplasticizer (Sp).

6MSAD

$40 \%$ of alluvial sand $+60 \%$ of dune sand + cement CEMI + water+ superplasticizer (Sp).

4MSAD

$20 \%$ of alluvial Sand $+80 \%$ of dune sand + cement CEMI + water + superplasticizer (Sp).

2MSAD

06 Dune sand + cement CEMI + water +
superplasticizer (Sp).

MSD

Table 3 Compositions of mortars mixtures 3. táblázat A habarcs keverékek összetétele

\begin{tabular}{|c|c|c|c|c|c|c|}
\hline $\begin{array}{c}\text { Designations } \\
\text { of mixtures }\end{array}$ & MSA & 8MSAD & GMSAD & 4MSAD & 2MSAD & MSD \\
\hline $\begin{array}{l}\text { Sp super- } \\
\text { plasticizer }\end{array}$ & 00 & $0.3 \%$ & $0.7 \%$ & $2 \%$ & $2.5 \%$ & $2.0 \%$ \\
\hline W/C & 0.51 & 0.51 & 0.51 & 0.51 & 0.51 & 0.60 \\
\hline $\begin{array}{rr}\text { Table } 4 & \text { The V } \\
\text { 4. táblázat } & \text { A kev } \\
& \text { menn }\end{array}$ & $\begin{array}{l}\text { / C ratic } \\
\text { rékek víz } \\
\text { iségei }\end{array}$ & $\begin{array}{l}\text { nd the am } \\
\text { ment tén }\end{array}$ & $\begin{array}{l}\text { nt of } S p \text { in } \\
\text { öi valami }\end{array}$ & $\begin{array}{l}\text { he mixtures } \\
\text { az alkalma }\end{array}$ & tt folyó & dalékszer \\
\hline
\end{tabular}

\subsection{Preparation of samples test for different mixtures}

According to AFREM recommendations, and before the start of the accelerated carbonation test, the samples which have undergone a cure in a humid environment (relative humidity greater than $95 \%$ or in water) for 28 days will be cut into cubes $(4 \times 4 \times 4) \mathrm{cm}^{3}$ (Fig. 2) and subjected to a preconditioning phase. This step consists of a phase where the samples (in cubes) are saturated with water for $24 \mathrm{~h}$, followed by a second phase where they are placed in an oven set at a temperature of $40 \pm 2{ }^{\circ} \mathrm{C}$ for $48 \mathrm{~h}$. Two opposite sides of each cube are covered with adhesive aluminium foil to guide the diffusion of the $\mathrm{CO}_{2}$. The samples are then weighed and placed in the carbonation chamber rich in $\mathrm{CO}_{2}(50 \%)$, regulated at a temperature of 20 ${ }^{\circ} \mathrm{C}$ and a relative humidity of $65 \pm 5 \%$ (Fig. 3).

Samples were removed from the carbonation chamber at different ages: 14, 28, 42 and 56 days. These are sawn in half (Fig. 4) and measurements of mass and depth of carbonation (by spraying the phenolphthalein solution at $0.1 \mathrm{~g} / 100 \mathrm{ml}$ )) were carried out.

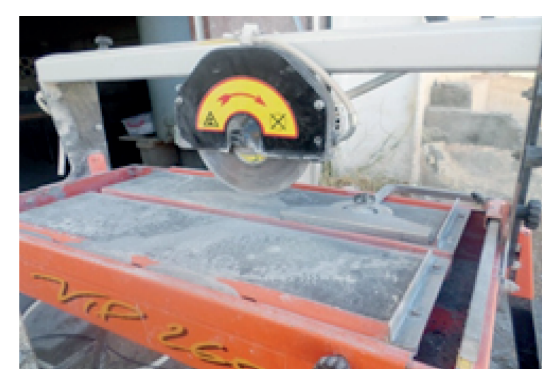

Fig. 2 Cutting samples into cubes $(4 \times 4 \times 4) \mathrm{cm}^{3}$ 2. ábra Kocka próbatestek $(4 \times 4 \times 4) \mathrm{cm}^{3}$-sé vágása 


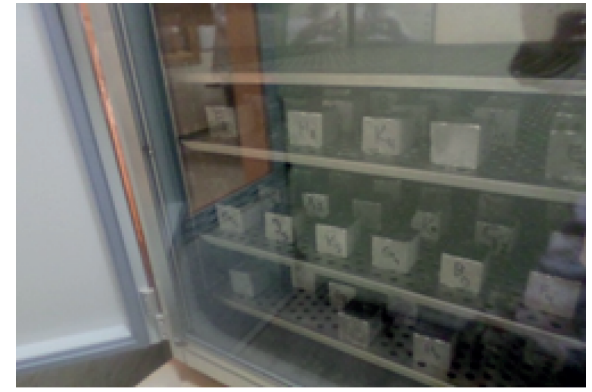

Fig. 3 The accelerated carbonation chamber

3. ábra A karbonátosodás gyorsító kamra

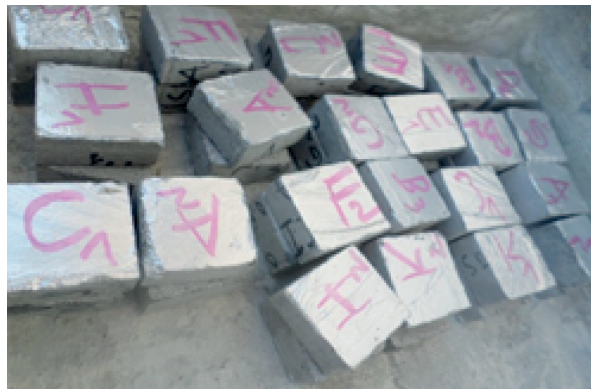

Fig. 4 Samples sawn in half before spraying with phenolphthalein 4. ábra A félbevágott minták a fenolftalein felhordása elótt

\section{Results and discussions}

\subsection{Compressive strength of different mortars}

The mechanical resistance tests were carried out on prismatic specimens $(4 \times 4 \times 16) \mathrm{cm}^{3}$ according to standard NF EN 12390-3. The results are shown in Fig. 5 and Table 5.

$\begin{array}{llllllll}\begin{array}{l}\text { Mortars } \\ \text { Mixtures }\end{array} & \text { MSA } & \text { 8MSAD } & \text { 6MSAD } & \text { 4MSAD } & \text { 2MSAD } & \text { MSD } \\ \begin{array}{l}\text { Compressive } \\ \text { strengths } \\ \text { at } 28 \text { days }\end{array} & 31.25 & 22 & 23 & 26 & 21.09 & 20 \\ (\mathbf{M P a}) & & & & & & \\ \end{array}$

Table 5 Compressive strengths at 28 days of mortars mixtures (MPa) 5. táblázat A habarcsok 28 napos nyomószilárdsága $(\mathrm{MPa})$

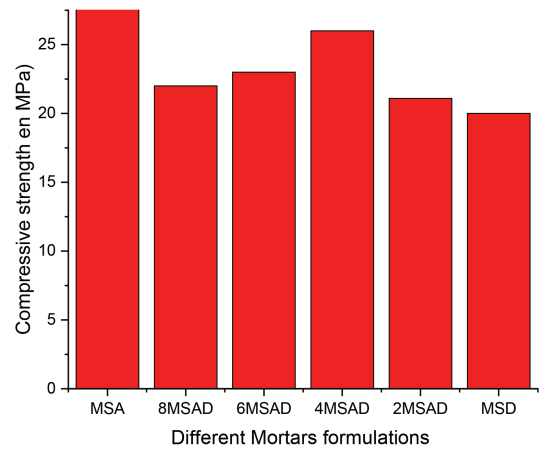

Fig. 5 Compressive strength at 28 days of mortars of different mixtures 5. ábra A habarcsok 28 napos nyomószilárdsága (MPa)

From the Fig. 5 it can be seen that alluvial sand mortars have a higher compressive strength than those of mixtures (alluvialdune) mortars. For the other mortars, they have an acceptable compressive strength [35]. These values are sufficient for general use as an exterior and interior plaster. It should also be noted that the E / C factor fixed at a value of 0.51 for all mixtures (except for MSD) has an influence on the value of the compressive strength.

\subsection{Accelerated carbonation test}

\subsubsection{Carbonation depth}

Fig. 6 shows the evolution of the carbonation depth as a function of the square root of the storage time of the mortars of different mixtures

\subsubsection{Mortars MSD and MSA}

From Fig. 6 it is clearly seen that the mortar based on dune sand alone (MSD) is the most carbonated (Fig. 6), this constatation is due to the fineness of the dune sand, which possesses a very porosity high allowing the penetration of carbon dioxide. From Fig. 7, it is noted that after 56 days of accelerated carbonation, the MSD mortar reaches a carbonation depth more than 10 $\mathrm{mm}$ (Figs. 7,8,9), which implies that more than $50 \%$ of the MSD sample has been completely carbonated.

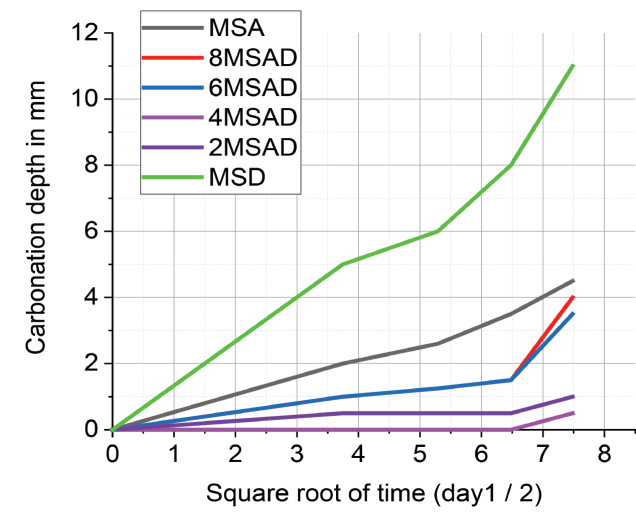

Fig. 6 Carbonation depth of the different mortars mixtures 6. ábra A karbonátosodási mélység értékei a különbözö minták esetén

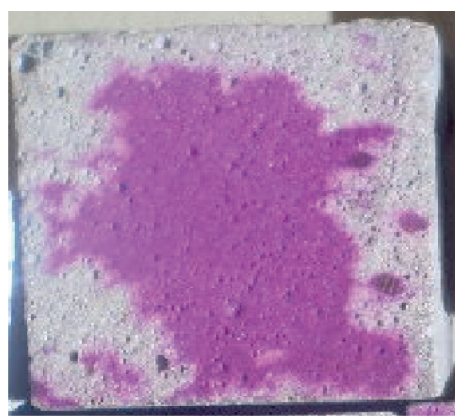

Fig. 7 MSD mortar after 56th days in accelerated carbonation chamber 7. ábra Az MSD habarcs 56 napnyi gyorsított karbonátosodási kamrában töltött idő után

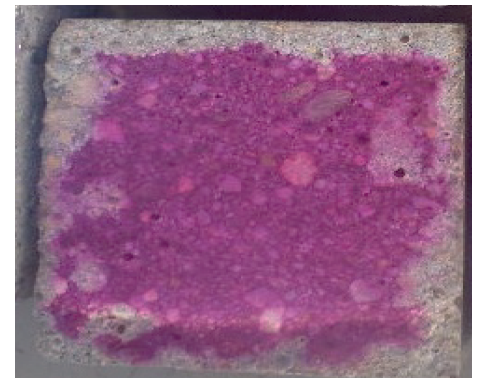

Fig. 8 MSA after 56th days in accelerated carbonation chamber

8. ábra Az MSA habarcs 56 napnyi gyorsított karbonátosodási kamrában töltött idö után 


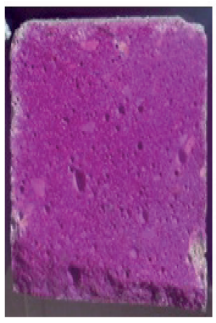

4MSAD

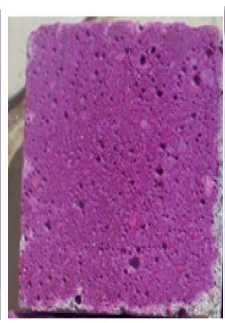

2MSAD

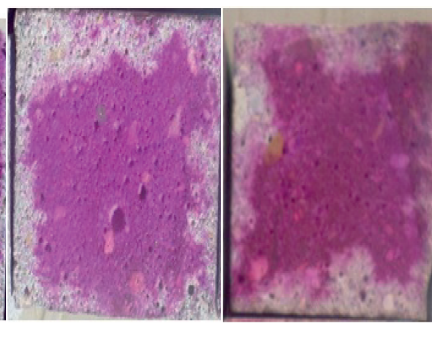

6MSAD

8MSAD
Fig. 9 Mortars of mixtures after 56 th days of accelerated carbonation

9. ábra Különbözö habarcs minták 56 napnyi gyorsított karbonátosodási kamrában töltött idő után

In addition, it has been found that the mortar MSA is less porous than MSD, and therefore, it is less sensible for carbonation. This is due to the uniform granulometry of the alluvial sand, but and despite its good compressive strength, it is found that it carbonates at the first days of conservation in carbonation chamber, which makes it less durable.

\subsubsection{Mortars 4MSAD, 2MSAD, 6MSAD, 8MSAD}

The depth of carbonation after the 56th day for the four mixing mortars (alluvial sand - dune sand) is shown in Fig. 9.

Fig. 9 clearly illustrates the beneficial effect of adding dune sand in reducing the carbonation front. Therefore, these four mortars are more durable. In particular, 4MSAD mortar and 2MSAD mortar. The influence of adding sand to dune is very clear. The granulometry of the sands of the mixtures has been modified in order to give less porous and more compact mortars. These results are consistent with the absorption capacity values indicated above which confirms the close relationship between the porosity and the durability of reinforced concrete structures against the carbonation.

\subsubsection{Evolution of the mass gain of the mortars during} the accelerated carbonation test

Monitoring the evolution of mass gains is also a parameter indicating the evolution of carbonation. The results of mass gain for the different mortars are illustrated in Fig. 10:

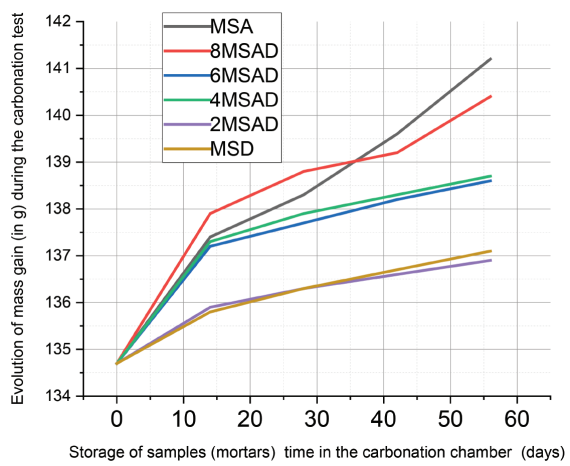

Fig. 10 Evolution of the mortars mass during the accelerated carbonation test

10. ábra A habarcs tömegének alakulása a gyorsított karbonizációs vizsgálat során

Carbonation protects concrete by modifying its porous structure. The $\mathrm{CaCO}_{3}$ formed closes certain pores, and therefore the total porosity decreases, and the carbonation reaction of portlandite leads to an increase in the volume of the solid phase. It is clearly seen that the MSA and 8MSAD mortar require $4 \%$ mass gain. This is probably due to the greater pore volume than that of other mortars (6MSAD-4MSAD-2MSADMSD) which show a mass gain between $2 \%$ and $3 \%$.

\section{Conclusions}

At the end of this study, the following conclusions can be drawn:

1. The mortars of mixtures (alluvial sand-dune sand) used as surface coatings of concretes against the carbonation phenomenon significantly reduce the carbonation depth by comparing them to the results obtained for MSD mortars (with dune sand alone) or with MSA mortars (with alluvial sand alone).

2. It has also been observed that the mortar composed of $40 \%$ alluvial sand and $60 \%$ dune sand with a CEMI Portland cement can reduce the carbonation front by more $50 \%$ compared to an ordinary mortar.

6. In addition, the mixture mortars studied through this work exhibit satisfactory compressive strengths suitable for general indoor and outdoor use.

8. With the use of dune sand which represents an abundant natural wealth, the repair of reinforced concrete structures will be less expensive, and it is hoped in the future to move away from use, industrial anti-carbonation coatings which sometimes present risks on the water, environment and on the structure at the same time.

\section{References}

[1] Arredondo Rea SP, Corral Higuera R, Gómez Soberón JMV, et al. Carbonation rate and reinforcing steel corrosion of concretes with recycled concrete aggregates and supplementary cementing materials. International journal of electrochemical science. 2012;7:1602-1610.

[2] Pollet V, Dooms B, Mosselmans G. Corrosion des armatures induite par la carbonatation du béton: comment s' en prémunir. Les dossiers du CSTC. 2007;2:1-7.

[3] Merah A. Concrete anti-carbonation coatings: a review. Journal of Adhesion Science and Technology. 2021;35:337-356. https://doi.org/10.1080/01694243.2020.1803594

[4] Merah A, Khenfer MM, Korichi Y. The effect of industrial coating type acrylic and epoxy resins on the durability of concrete subjected to accelerated carbonation. Journal of Adhesion Science and Technology. 2015;29:2446-2460. https://doi.org/10.1080/01694243.2015.1067004

[5] Aguiar JB, Júnior C. Carbonation of surface protected concrete. Construction and Building Materials. 2013;49:478-483. DOI: 10.1016/j. conbuildmat.2013.08.058[6] Almusallam AA, Khan FM, Dulaijan SU, et al. Effectiveness of surface coatings in improving concrete durability. Cement and Concrete Composites. 2003;25:473-481. https://doi.org/10.1016/S0958-9465(02)00087-2

[7] Zafeiropoulou T, Rakanta E, Batis G. Performance evaluation of organic coatings against corrosion in reinforced cement mortars. Progress in Organic Coatings. 2011;72:175-180 https://doi.org/10.1016/j.porgcoat.2011.04.005

[8] Beushausen H, Burmeister N. The use of surface coatings to increase the service life of reinforced concrete structures for durability class XC. Materials and Structures. 2015;48:1243-1252. DOI: https://doi.org/10.1617/s11527-013-0229-8

[9] Saricimen H, Maslehuddin M, Iob A, et al. Evaluation of a surface coating in retarding reinforcement corrosion. Construction and Building Materials. 1996;10:507-513. http://worldcat.org/issn/09500618 
[10] Sanjuán MA, del Olmo C. Carbonation resistance of one industrial mortar used as a concrete coating. Building and Environment. 2001;36:949-953. https://doi.org/10.1016/S0360-1323(00)00045-7

[11] Huang NM, Chang JJ, Liang MT. Effect of plastering on the carbonation of a 35-year-old reinforced concrete building. Construction and Building Materials. 2012;29:206-214.

https://doi.org/10.1016/j.conbuildmat.2011.08.049

[12] Papadakis VG, Fardis MN, Vayenas CG. Effect of composition, environmental factors and cement-lime mortar coating on concrete carbonation. Materials and Structures. 1992;25:293-304.

[13] Zhang G, Xie Q, Ma C, et al. Permeable epoxy coating with reactive solvent for anticorrosion of concrete. Progress in Organic Coatings. 2018;117:29 34. https://doi.org/10.1016/j.porgcoat.2017.12.018
[14] de Oliveira Andrade JJ, Possan E, Squiavon JZ, et al. Evaluation of mechanical properties and carbonation of mortars produced with construction and demolition waste. Construction and Building Materials. 2018;161:70-83. https://doi.org/10.1016/j.conbuildmat.2017.11.089

[15] EN B. 934-2: 2009+ A1: 2012, Admixtures for concrete, mortar and grout, Part 2, Concrete admixtures-Definitions, requirements, conformity, marking and labelling. Br Stand. 2012;

\section{Ref.:}

Korichi, Youssef - Merah, Ahmed - Khenfer, Med Mouldi - Krobba, Benharzallah: Development a cement mortar based on dune sand used as an anti-carbonation coating of concrete

Építőanyag - Journal of Silicate Based and Composite Materials, Vol. 74, No. 1 (2022), 27-31. p.

https://doi.org/10.14382/epitoanyag-jsbcm.2022.5

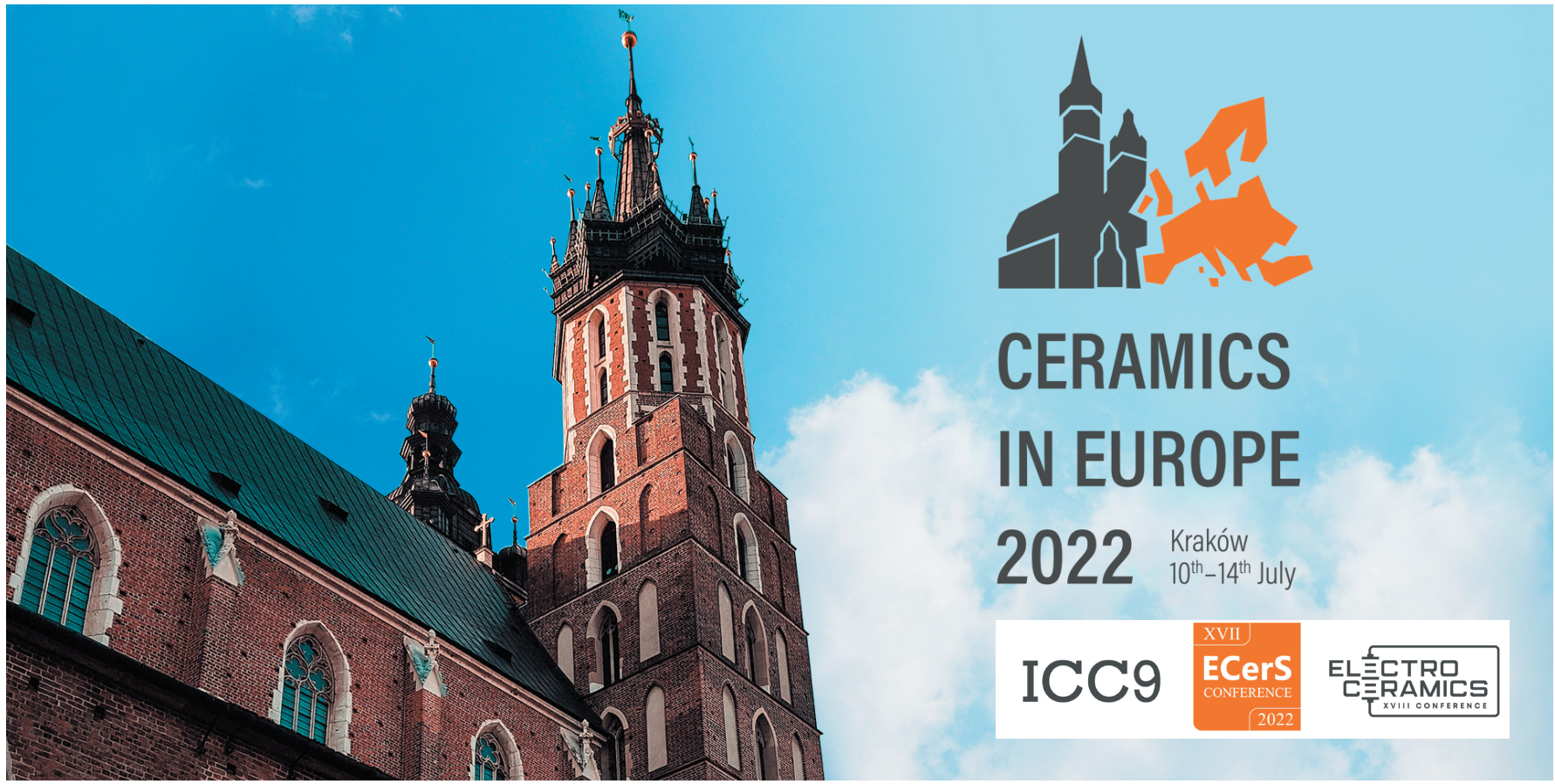

Invitation to Ceramics 2022

Dear Colleagues and fellow Ceramists,

As we all know only too well, the global pandemic has had some tragic consequences as well as disrupting our personal and professional lives very significantly. Whilst many valiant efforts have been made to continue with meeting and conferences online, our ability to talk face-to-face with each other and enjoy each other's company has in many cases simply not been possible. However, the good news is that, hopefully, things look as if we may be able to start planning again for a world where we can meet, learn and laugh together.

The undersigned below would very much like to invite all of you to a meeting that we hope will help to re-unify the worldwide ceramics community in one place and at one time. By agreement between the European Ceramics Society, the International Ceramic Federation and the International Committee of Electroceramics, and with excellent international co-operation, it has been decided to combine three major conferences into a single major conference. We realise just how busy 2022 is likely to be as many conferences that have had to be postponed are now jostling for timeslots - and attendees' budgets. Our move will see ECerS XVII, ICC9 and Electroceramics XVIII all held simultaneously in Krakow, Poland, 10-14 July 2022. A single registration fee will provide access to all three conferences, which are being hosted under the common title Ceramics in Europe 2022.

We truly hope that you will let this wonderful and ancient city with an old university and scientific tradition become the background for a tremendously fruitful meeting, which will give us all a much-needed boost for achieving progress again in our professional lives for the benefit of our world. 